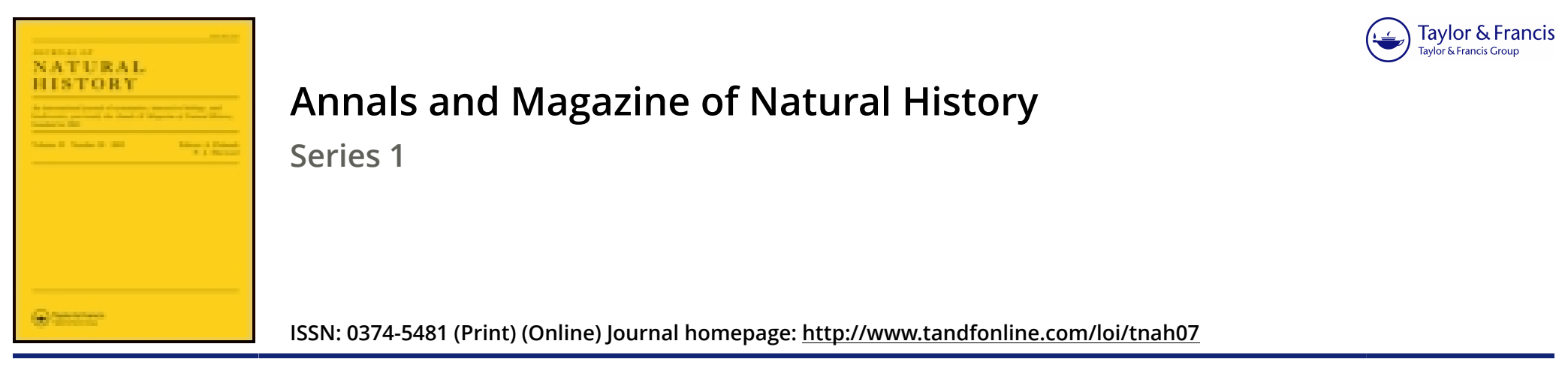

\title{
XVI.-Further observations on the ornithology of the neighbourhood of Calcutta
}

\section{Edward Blyth}

To cite this article: Edward Blyth (1844) XVI.-Further observations on the ornithology of the neighbourhood of Calcutta, Annals and Magazine of Natural History, 14:89, 114-125, DOI:

$10.1080 / 037454809495150$

To link to this article: http://dx.doi.org/10.1080/037454809495150

\section{曲 Published online: 23 Dec 2009.}

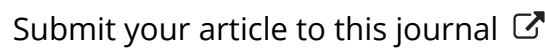

Q View related articles $\longleftarrow$ 


\section{Mr. E. Blyth on the Ornithology of the neighbourhood of}

From an examination of Cystoseira under very unfavourable circumstances, viz. of dried specimens, and the fruit probably immature, I am inclined to believe that spores and sporidia occur in the same conceptacles. There is some reason to believe that the same arrangement prevails in Halidrys.

In the Sporiferce other subdivisions suggest themselves: in some the spores are erumpent, breaking out beneath the cuticle as inPadina; in others, as Striaria, the spores are unaccompanied by filaments, and Asperoccocus may be cited where the spores are so accompanied. Should Desmarestia and Dichloria be found sporiferous, they will be properly placed beside Halyseris.

In Sporidifera, as in Sporifera, there occur membranous and filamentous species.

A question may arise as to the relative importance of spores and sporidia; there cannot be a doubt that both are equally capable of propagating the species.

The above can only be considered an imperfect attempt, a mere outline or suggestion; those who possess a thorough knowledge of foreign as well as British species are alone entitled to speak with confidence on the subject, and to such knowledge the author of this attempt can lay no claim, and must leave his suggestions to be added to and amended by more experienced algologists.

XVI.-Further Observations on the Ornithology of the neighbourhood of Calcutta. By Edward Blyth, Curator to the Museum of the Asiatic Society of Bengal. With Notes by H. E. StrickLand, M.A.

[Concluded from p. 48.]

No. 127. (vol. xii. p. 165, supra) I observed great numbers of $H i$ rundo rustica a few weeks ago, skimming over the salt-water lake a little above Calcutta.

No. 127 a. Hirundo daurica (erythropygia, Sykes) was observed in considerable numbers in the middle of April upon the Calcutta esplanade.

No. 128. This is also the $M$. dukhunensis of Sykes. I observe that the $M$. picata of Franklin, which is the $M$. variegata, Latham, is mentioned as having been received from Calcutta in the 'Rev. Zool. par la Soc. Cuv.' 1839 , pp. 40 and 138 (this being the only volume of the useful work in question which I have for reference); but I have never heard of the species being obtained in this neighbourhood, having only received it from Central and Southern India.

No. 130. This remarkable species, which is the type of my genus Nemoricola, is the Bergeronette grise des Indes of Sonnerat, upon which Latham founds his Motacilla indica. I obtained one beautiful specimen during last cold season. 
No. $130 a, b$. The genus Budytes was strangely omitted in my catalogue, though two species are common: B. citreola, which is less abundant, and of which 1 have one example with a jetty-black back, and $B$. beema, Sykes, which is extremely common, and approximates the B. neglecta, Gould. The sexes of this bird appear to assemble in separate focks; at least I have two or three times vainly sought to pick out a female from among a flock of males, and I think that I have also observed a flock of females only. The note of this bird is much weaker and less articulate than that of B. flava of Britain. The young males assume yellow under-parts in February and March, and a dull leaden-blue cap and nape, having a strongly defined whitish supercilium; in old males the under-parts are much brighter yellow, and the head and nape are fine dark ashy-gray, with no trace of supercilium, the throat continuing white at all ages, spreading laterally to contrast with the dark ear-coverts. A black cap I have never seen, though Mr. Jerdon includes B. melanocephala among the species of Southern India, and doubts its distinctness from B. beema, which he identifies with $B$. neglecta. See also Mr. Drummond's remarks on the species of the Ionian Islands, vol. xii. p. 416 ante. Specimens with the supercilium slightly developed, or with only a trace of it, are also here common*.

Of Anthi I have an extensive series of Indian species, but have obtained no additional ones in this vicinity.

No. 134. This lark I heard singing delightfully, soaring over the dry rice-stubble along the banks of the river during a late excursion; its song and mode of delivery closely resembling that of the British skylark. No. 135 appears to be identical with $A$. gulgula, apud Jerdon, and I have not obtained a second example of it in this part. I have also a very extensive series of Indian larks and Mirafre to describe, as soon as I can get leisure to do so.

No. 139 is also Alauda gingica of Latham, after Sonnerat.

No. 14l. I observed a large flock of this species during my late excursion, feeding upon the seeds of the reeds, \&c. which choke up the moat surrounding the old fort at Budge Budge, a most capital locale for the researches of the ornithologist.

No. 142. I have now obtained wild specimens of Euplectes striatus, which I had previously procured only in the bird-shopst.

No. 145. Spermestes malacca, auct.

No. 149. For a monographic notice of the species of Phyllornis,

* The species of Budytes are as yet by no means satisfactorily made out. It appears clear however that the gray-headed species of India and Malasia (Motacilla bistrigata, Raffles) is the same with the cinereocapilla of Southern Europe. The young of this in Europe has a yellow superciliary streak, and I have a similar specimen from India. It appears from Mr. Blyth's account that the Indian bird with a white supercilium (B. beema, Sykes) is also the young of the bistrigata; and if this be certainly the case, the true B. flava of North Europe (B. neglecta, Gould) must be distinct, as the grayheaded birds without a white supercilium are never found in the North of Europe.-H. E. S.

$\dagger$ E. striatus, Blyth, seems to be the $E$.faviceps, Swainson, 'Animals in Menageries,' p. 310.-H. E. S. 
v. Chloropsis, vide J. A. S. B. no. 59. p. 955 et seq. I cannot just now enlighten Mr. Strickland on the subject of the structure of these birds, further than by remarking that the species with a curved and pointed bill have also a meliphagous conformation of tongue, by means of which, when caged, they will sip at sweets, but they require to be fed on the usual diet given to insectivorous birds. Vide Tickell's list for a slight notice of their habits *.

No. 153. Dicaum Tickellia has a pale flesh-coloured bill with dusky tip. Vide J. A. S. B. no. 59. n. s. p. $983 \dagger$.

Nos. 154 and 155. My Vinago militaris is the species so designated by Gould, having an ash-coloured belly, and which abounds in Bengal and Nepal. That of Southern India, $V$. (or Treron) chlorigaster, nobis, I have once only obtained in this part, and have received specimens of it from Mr. Jerdon and others. I cannot recognise, however, the difference of size and structure of bill mentioned by Mr. Strickland $\ddagger$, the only distinctions consisting in the green or yellowishgreen belly of $T r$. chlorigaster, the absence of this colour on the basal half of the tail, and there is also at most but a faint trace of the same hue upon the forehead. Tr. bicinctus of India generally, and also Arracan, differs from $T r$. vernans of the Malay countries, in having the forehead to beyond the eyes, the throat and sides of the neck bright green, the occiput alone gray, and the pinkish lilac hue surmounting the orange-colour of the breast diminished in quantity, and not spreading to the sides of the neck, while in Tr. vernans it .quite surrounds the neck; the tail also is broadly tipped with ashcolour, appearing as ashy-white beneath, this character serving at once to distinguish the females, while the female Tr. aromaticus may be known from that of Tr. bicinctus by its ash-coluured forehead.

The Sphenocercus (G. R. Gray) cantillans, nobis, J. A. S. B. xii. 166, is said to occur in the Soonderbuns, though I rather doubt it,

* Having lately procured specimens of Phyllornis in which the tongue is preserved, I am now satisfied that they belong to the Tenuirostres and not to the Pycnonotina. - H. E. S.

$\uparrow$ There can now be no doabt that Diceum Tickellice is the Certhia erythrorhyncha of Latham, and the latter specific name stiould be adopted.H. E. S.

This was owing to my having (at p. 38 , supra) assumed as the true militaris a Malayan bird which now appears to be distinet and undescribed. It is the largest species of Treron known, with the beak very strong and almost Vulturine in form. Tetal length 14 inches; beak to gape 1 inch 4 lines; beight $5 \frac{1}{2}$ lines; wing $7 \frac{3}{4}$ inches; medial rectrices 5 inches, external $4 \frac{1}{2}$. My specimens are wholly greenish-gray above, greater covers and quills slaty-black, the middle covers and tertials margined externally with bright yellow, four medial rectrices greenish-gray, the rest slate-coloured tinged with green, and broadly tipped with light gray. Below pale grayish-green, a large patch on the breast of dull orange. Lower tail-covers chocolate (in a younger specimen gray, tipped with buff); beak plumbeous, pale yellow towards the end; legs flesh-colour. This species may be called Treron magnirostris. The true militaris of Temminck and Gould, which is the phonicoptera of Latham, inhabits Northern Iudia, as shown by Mr. Blyth, and the chlorigaster, Blyth (which name is prior to mine of Treron Jerdoni), occurs in the South of India.-H. E. S. 
as the group to which it belongs appears to be monticolous. The Sph. oxyurus, in addition to Sph. sphenurus, inhabits Bengal and Assam.

Respecting the Columba risoria group, I consider that I have three distinct species before me :-1. that so commonly kept in cages, both here and in Europe, and which I presume is the North African species, of a pale isabelline colour; 2. the South African Turtur vinaceus ; and 3. that common throughout India, with bluish-gray wings and tail, and altogether more resembling no. 2, but having the general hue paler, the under-parts much paler, and no dusky tinge upon the rump ; its note or coo also differing from that of no. 1. I am not acquainted with the two varieties of size mentioned by Major Franklin, but the Bengal species measures $12 \frac{3}{4}$ to 13 inches long, by $19 \frac{1}{2}$ to $20 \mathrm{in}$. in alar extent; wing from bend $6 \frac{3}{8}$ to $6 \frac{5}{8}$ in., and middle tail-feathers $5 \frac{1}{8}$ to $5 \frac{3}{8}$ in.*

No. 161. I am not satisfied that Mr. Strickland is correct in regarding the wild pigeons which I mentioned as being brought somewhat abundantly to the London markets as the young of $C$. livia. The bird I alluded to is well known to Mr. Bartlett, who could procure any number of specimens ; and it is remarkable that individuals with barred wings appear never to occur among them. It is rot improbably the blue rockier pigeon noticed by Gilbert White.

No. 163. This is the Perdix gularis of Temminck, and Chickore of Bengal sportsmen, so termed from its call, which much resembles that of the red-legged $P$. chukar of the Himalaya. It abounds in all the heavy jungles eastward of the Ganges, extending northward to the Malda range of hills, if not beyond.

The Francolinus or Perdix lunulatus of Valenciennes is evidently identical with the Curria partridge of Hardwicke, termed F. Hardwickii by Gray, and recently $F$. nivosus in the 'Mag. de Zoologie.' It comes chiefly from the country westward of Agra, and Mr. Jerdon has also recently obtained it in the south; but an experienced sportsman assures me that he doubts exceedingly the existence of this bird in Bengal, though I observe that a double-spurred partridge is mentioned to occur in the Monghyr district, which I must inquire about.

No. 166. Coturnix coromandelica is, I nm told, very abundant during the rains, at which season it breeds.

No. 168. This I now consider must have been the young of $\mathrm{Co}$ turnix chinensis.

Nos. 169 and 170. Mr. Jerdon has now ascertained, for certain, that the Hemipodius taigoor of Sykes is the male of his H. pugnax, the latter only having the black stripe down the throat and breast, besides being larger. This corresponds with what I have also observed of its Bengal representative, which appears always to be somewhat smaller than that of Southern India, and decidedly less rufous :

* The pale turtle-dove kept in cages is a domestic variety unknown in a wild state. The North African bird is the same as the Indian; it is the true Turtur risorius, Linn. (sp.), and differs from T. vinaceus of S. Africa in having the lower wing-covers light and the lower tail-covers dark, while in $T$. vinaceus they are the reverse.-H. E. S. 


\section{Mr. E. Blyth on the Ornithology of the neighbourhood of}

from Nepal I have received a third closely-allied species, the $H$. atrogularis of Eyton, but which will bear the prior name of plumbipes, Hodgson, published in 1837 , and which abounds in the Tenasserim provinces, and also in the vicinity of Singapore. There are two other Bengal species, additional also to Dussumieri; one of them the Turnix tanki of Buchanan, which likewise inhabits Nepal, and the other undescribed, which Mr. Jerdon has also obtained in the south. $I$ believe that he has yet another Indian species of this group, collected by Lord Arthur Hay.

No. 171 a. Add Gallus bankiva, brought to me fresh from the vicinity.

No. 173 et seq. Herons, Bitterns, \&c. Add Ardea nobilis, nobis, and Botaurus sinensis (Ardea sinensis, Lath., and A. lepida, Horsf.); I have also obtained two other specimens of Botaurus stellaris, and likewise the B. favicollis (Ardea flavicollis, Lath., and A. nigra, Vieillot).

The Indian white Egrets are difficult to understand. There are three sizes of them, of which the smallest is the common $A$. gar$z e t t a$, which is very abundant. The $A$. orientalis of Hardwicke's published drawings may, I suspect, be safely referred to this species, although the beak is represented to be wholly black, and the toes are coloured much too orange instead of greenish yellow. This species always sheds its crest prior to dropping its dorsal plumes; and the colour of its toes, contrasting with its black tarsi, at once distinguishes it.

The large white Egrets have, at all ages, the bill sometimes orange-yellow, sometimes wholly black, and sometimes the basal part of the bill is yellow and its terminal part black, varying in proportions. In one fine adult before me, with a fully developed train, the bili is about half yellow and half black; in another there is a yellowish ring only near the base; and I have observed the same differences in birds of the first year. The yellow-billed specimens constitute the $A$. flavirostris, Wagler, and the black-billed are probably the $A$. modesta, Gray, though I have never seen the train elongated as in Hardwicke's figure*.

Of the third size, which is intermediate, I once had several dozens of the young brought me, all of which had yellow bills, slightly tipped with dusky-black ; what few adults (with dorsal trains) I have seen had the bill wholly yellow, with one exception only, wherein the terminal two-thirds are black; and the A. nigrirostris of Hardwicke and Gray appears to represent a specimen with bill wholly black. In the Egrets of this size, the wings measure 11 or $11 \frac{1}{2}$ inches in length, bill to forehead $3 \mathrm{in.}$, tarsi $4 \frac{1}{2}$ in., the claws straighter and more elongated than in the great Egrets. The yellow-billed specimens constitute the $A$. putea, Buch. Hamilton MS.

The members of this group are now putting forth their nuptial

* What are the measurements of these large Indian Egrets ? and do all the varieties referred to present the same dimensions? The Egrets of Southern Europe are almost as puzzling as those of India, and we shall look with interest for any light which Mr. Blyth can throw upon them.-H. F. S. 
dress, and I trust this season to come to some distinct understanding of the variations here noticed.

No. 188. I did not observe a single specimen of this 'Adjutant' during the last period of the sojourn of the common great species.

No. 189. A young male of the Bengal jabiru, moulting into the adult plumage, measured $4 \mathrm{ft}$. 5 inches in total length by $7 \frac{1}{4} \mathrm{ft}$. in alar expanse ; wing $23 \frac{\mathrm{I}}{2}$ in. ; tail $8 \frac{\mathrm{I}}{2}$ in.; beak to forehead 13 in., and 2 in. deep at base ; bare part of tibia 9 in.; tarsi 13 in.; middle toe and claw $4 \frac{1}{2}$ in. Another male, in full plumage, but retaining a few scattered nestling feathers, showing its age to be about the same as that of the last, corresponds exactly in its dimensions. An old female is smaller, especially its legs, the bare part of the tibia measuring but $7 \frac{\pi}{2}$ inches ; tarsi scarcely $11 \frac{1}{2}$ in., and middle toe and claw 4 in.; bill to forehead $12 \frac{1}{2}$ in., and closed wing 22 in. Bill black; irides of young dark, and legs dark brownish-lake; but the latter appear, in the adults, to have been coral-red (referring however to Mr. Jerdon's catalogue, I perceive that he assigns " rosy-red" as the colour of the legs of this species). The mouth, anterior scapularies, smaller wing-coverts, primaries and secondaries, and the entire under-parts, are white : head and neck brilliant steel-black, with green reflections ; the crown reddish-purple, margined with brownish-green, and surrounded by steel-purple: posterior scapularies, tertiaries, the two greater ranges of wing-coverts, and the tail, bright green-black, varied with steel-blue. The young have the neck and upper parts brown, a little green-glossed, and indications of white upon the smaller wing-coverts. This bird is easily tamed, and if brought up from the nest may be suffered to range at large with impunity; but it is apt to attack strangers, its beak constituting a most formidable thrusting weapon*.

No. 196 is perfectly identical with the European species, of which I have received a specimen from England, and have obtained two others in this neighbourhood, besides several from various parts of India.

No. 198 a. I have obtained one specimen of a lapwing, closely resembling the Vanellus leucurus (Licht.) figured by Savigny, and which is stated in Griffith's work also to inhabit Tartary; but it has not the rufous-isabelline hue of the Egyptian bird, according to the figure alluded to, nor the defined ash-coloured patch on the breast : being chiefly of a grayish-brown, glossed with purplish-red upon the back, the breast inclining to cinereous, throat white, and belly dull rosy-white or somewhat deeply blushed; tail pure white; primaries black, and the greater wing-coverts broadly tipped with white, the next range more narrowly so ; bill black, and legs bright yellow ; no trace of crest, wattles, or of spurs on the wing; the irides reddishamber. Length (of a female) 11 inches by 23 in. in spread of wing, the closed wing $6 \frac{3}{4}$ in.; bill $1 \frac{1}{8}$ in., and tarsi $2 \frac{5}{8}$ in.

* It appears from the above description that the Indian Mycteria is the same with the $M$. australis from Australia. It cannot I think be referred to the $M$. asiatica, Lath., as I before conjectured, and we have yet to learn what bird is indicated by the latter name.-H. E. S. 
Of the Lobivanellus cinereus, nobis, I procured many examples duing the late cold season.

Nos. 201 and 202 I presume to be Ch. Geoffroyi and Ch. Leschenaultii.

No. 204. Also several specimens of Charadrius Cantianus.

No. 206. This is called Himantopus asiaticus by M. Lesson, in the erroneous supposition that the bird has never a black cap, as in the European species.

No. 209 is Totanus stagnatilis, Bechstein; also T. tenuirostris, Horsfield, and figured by two or three names in Hardwicke's published drawings. Respecting the greenshank, no. 208, I certainly was never satisfied of the alleged distinctness of the so-called glottoides, of which I have seen many specimens from the Himalaya, all of which were decidedly T. glottis, as Mr. Strickland suggests.

No. 212 is the European wood-sandpiper, commonly measuring $8 \frac{3}{4}$ by 16 inches ; wing 5 or $5 \frac{1}{8}$ in. Dr. Horsfield's T. affinis is probably a stretched skin of the same*. Judging from the few specimens brought to the bazar, I was greatly astray in asserting $T$. ochropus and $T$. hypoleucos to be somewhat rare. The latter is excessively abundant a little way down the river, along its banks, on those of the nullahol (natural or artificial canals) communicating with it, and about the jheels or marshy lakes; the latter being also favourite haunts of $T$. ochropus.

No. 216 et seq. Terekia javanica was rather plentiful at the commencement of last cold season; Tringa platyrhyncha less numerous than during the preceding season; Tr.Temminckii common; Tr. alpina obtained once only, a single specimen. I have mentioned that Tr. canutus has been once obtained by Mr. Jerdon, who has also procured a single example of Calidris arenaria. Towards the mouth of the river, Strepsilas interpres occurs, and probably also Hamatopus longirostris, which, with Numenius phreopus, I have received from both sides of the bay. The Eurhinorhynchus orientalis, nobis, has never yet occurred to me. I have procured one fine fresh specimen of a common woodcock, which species is probably not so rare as its haunts are inaccessible; and as regards the snipe referred to gallinago, it appears always to have fourteen rectrices $\dagger$. Hardwicke's figure of Scolopax Horsfieldi, Gray, has certainly not much the appearance of Sc. stenura, but I doubt its being a peculiar species.

No. 231. I shall describe the Indian Porphyrio, which I cannot exactly satisfy myself is Dr. Horsfield's Javanese species, and also another undetermined Porphyrio in the museum. The former measures 17 or 18 inches by 30 to 33 in. ; wing $8 \frac{3}{4}$ to $9 \frac{1}{2}$ in. ; tail 4 in.; bill to gape $1 \frac{1}{2}$ in. ; tarsi $3 \frac{1}{2}$ to $3 \frac{3}{4}$ in. ; middle toe and claw averaging $4 \frac{1}{2}$ in.; frontal shield large and broad, extending beyond the eyes,

* I have lately examined the original specimen of Dr. Horsfield's T. affinis, which is certainly the glareola. It measures about 8 inches in length, the published measurement of 10 inches having been an error.-H. E.S.

+ Be it remembered that the number of tail-feathers is subject to variation in the British wild swans, a fact I have observed both in Cygnus musicus and $C$. Bewickii. 
and squared posteriorly. General colour purple, the fore-neck and breast verditer, and wings the same inclining to greenish; crown somewhat dusky, the sides of the face and immediately around the frontal shield dull white; lower tail-coverts pure white; the medial portion of the belly dusky-slate; irides bright red-brown; bill and frontal disc dark coral-red ; and legs and toes reddish carneous, with dusky lead-coloured joints *.

The other species is probably either from the Moluccas or from China. Its size is rather superior to that of the Indian one, the bill larger and more robust, but the frontal shield smaller, rounded posteriorly, and not reaching beyond the eyes. In colour it is distinguished by having the back and scapularies green, the wings purple, the sides of the face dark, passing into verditer, and the crown, occiput and hind-neck dusky-purplish; all the purple of this species being darker and less vivid than that of the other. If undescribed, I propose to term it $P$. dorsalis $\uparrow$.

No. 232. Gallinula parvifrons, nobis. Distinguished from the European species by its inferior size and much less developed frontal shield ; in other respects quite similar, as are also its habits and note. This bird is the G.akool of Mr. Jerdon's list ; but I have also obtained the true Porzana akool (Rallus akool of Sykes) in this neighbourhood, a species having dark under tail-coverts, and the legs dark reddish-brown.

Nos. 234 and 235. These are identical; the Rallus rufescens, Jerdon, referring to the young female Gal. lugubris, Horsfield, vel $G$. plumbea, Vieillot, of which I have obtained several examples $\$$.

Nos. 239 and 240. Both of these are common.

No. 241 . The only flamingo which I have myself obtained here is Phenicopterus minor, but there is a Calcutta specimen of $P h$. antiquorum, Tem., in the museum, and I have received others from the upper provinces, \&c.

Of Ducks, the only additional species to be mentioned is the Anas formosa, Gmelin, of which I procured a splendid male, shot on the salt-water lake . Length $16 \frac{1}{2}$ by 27 inches. Bill black; feet dingy yellowish-olive, darker on the webs; irides dark; the tracheal osseous vesicle small. Anas boschas has not yet occurred, though Mr.

* It is evident from the above description that the Indian Porphyrio is not the smaragnotus, in which the back is of a pure olive-green. Neither can it, I think, be the indicus of Dr. Horsfield (smaragdinus, Temm.), which is only 15 (not 19) inches long, and in which the back is described as nearly black with a greenish tinge. The Indian bird appears from the description to approach most nearly to the European $P$. antiquorum, Edwards, pl. 87, in which however the frontal shield is said to be rounded. Mr. Blyth's second species seems to be the smaragnotus of Temminck, in which case the specimen was probably brought from S. Africa.-H. E.S,

+ This approaches the P. erythropus of Stephens, which that author identifies with $P$. smaragnotus, Tem.

¥ Dr. Horsfield's Gallinula gularis is also the young of his lugubris.H. E. S.

$\$$ This is a widely different species from the 'bimaculated duck' of English authors. 


\section{Mr. E. Blyth on the Ornithology of the neighbourhood of}

Hodgson has met with it in Nepal, where, however, I have reason to suspect that it is very rare. On the Indus it appears to be tolerably common. This bird is represented in India generally and in the Burmese countries by $A$. pacilorhyncha, which in many parts is extremely common, and here is more so than I formerly supposed.

No. 262. This is the true Podiceps minor, though referred to $P$. phillipensis by Mr. Jerdon. P. cristatus is also found in the upper provinces.

Nos. 265 and 266. Both of these pelicans are common in suitable localities, and they both vary exceedingly in size, as much so as $\mathrm{Nu}$ menius arquata and Limosa melanura. I suspect that the females are always much smaller, but cannot pronounce upon this subject at present, as I find that I omitted to add the sex, when subsequently ascertained, to my notes on a number of recent specimens. Two examples of $P$. onocrotulus measured respectively $5 \frac{1}{2} \mathrm{ft}$. by $8 \mathrm{ft}$. $10 \mathrm{in}$.; wing 26 ; tail 8 ; bill to forehead $14 \frac{1}{2}$ in., and tarsi $5 \frac{1}{2} \mathrm{in}$.; and $4 \mathrm{ft}$. 8 in. by $7 \mathrm{ft} .10$ in., 23, 7,11 and 5 . Another stuffed specimen, which appears conspicuously larger than the first of these, has the bill $15 \frac{1}{2} \mathrm{in}$., and wing $27 \mathrm{in}$. The small one has the supplementary glistening reddish-brown feathers on the breast, analogous to the supplementary feathers of the cormorants when in breeding costume. Of the other species, which I term rufescens with considerable doubt. an adult female measured $4 \frac{1}{2} \mathrm{ft}$. by $7 \frac{1}{4} \mathrm{ft}$; ; wing $21 \mathrm{in.;}$ tail $7 \mathrm{in}$.; bill to forehead $12 \frac{1}{4}$ in. : a young female is still smaller, and a young male much larger, the bill measuring $14 \frac{1}{2}$ in., and the wing $23 \frac{1}{2}$ in. This species has a row of dark spots along each lateral half of its upper mandible, more or less developed ; the pouch also is commonly more or less spotted, sometimes very thickly so: the feathers of the head and neck are very different from those of $P$. onocrotalus, being larger, of lax and disunited texture and inclining upwards, as does also the occipital crest ; irides pearly-white in the adult, those of the other being bright brownish-red. Colour of the adult white, slightly blushed, and more conspicuously tinged with yellow, especially also the wings, which have lengthened slender hackles impending their coverts of a strongly marked yellowish cast; back and rump duil brownish-rosy; head and neck tinged with ashy, from the bases of the feathers appearing externally; and breast also covered with dingyyellowish or yellowish-brown hackles : pouch ashy; and legs leadenblack, slightly tinged with greenish; the claws white. The young have the upper parts brown, the feathers edged paler. I have sent specimens to the museum of the India-house.

Nos. 270 and 271 . These must both be referred to Gelochelidon of Brehm. Both are numerous; the former being nos. 400 and 403 of Mr. Jerdon's list, and the latter nos. 398 and 404 of the same. Add Anoüs tenuirostris and Rhynchops flavirostris.

No. 274. Of this I have since procured a second specimen.

On casting my eye over the original list, bearing in mind all the additions and corrections which have been here noticed, I find that I have obtained about 293 species of birds in this immediate neighbourhood during a sojourn of two years and a half; and not count- 
ing nos. 1, 4, 26, 45, 65, 67, 73, 82, 94, 117, 143, 149, 163, 171, 195 and 272 , several of which might however be safely added. $\mathrm{Mr}$. Jerdon's original list of the peninsular species generally (of the hills as well as of the plains) numbered 407 species; but of these several are merely nominal, though he has since added very considerably to that number. If I had included all which I know to inhabit Bengal, my list would have been much more extensive; but I have confined myself exclusively to the species which I have procured within a few miles of Calcutta : and so far are even these from being yet exhausted, that I have obtained no less than three additional Raptores while writing out the present paper, namely Pernis maculosa, Lesson (for certain), Circaëtus gallicus and a small Accipiter, which is probably the Khandesra hawk long sought for by Mr. Jerdon. With respect to my own opportunities for out-door observation, I may here repeat that they have been hitherto extremely few, for during the whole of the past year I was only one day absent from the museum; but I have now just returned from a week's excursion in the direction of the Soonderbuns, and have no intention of remaining quite so much at home for the future. Even in that short trip I found species of fish to be quite plentiful, which I had never, or but very rarely, seen in the bazar; among them a splendid undescribed Scicena, taken in abundance in the middle of the stream, which $I$ had only once or twice previously met with : and so far as birds are concerned, the extreme plentifulness of Totanus hypoleucos, and also the commonness of $T$. ochropus I was previously unaware of ; having formed a judgement from the few brought by the bazar shikarees in comparison to the multitudes which they bring of T.glareola and some others.

Postscript.-Since the above was in type, a letter has been received from Mr. Blyth, dated Calcutta, May 9, 1844, of which the following are extracts :-

I avail myself of a steamer's departure direct from this to Suez, to forward another communication to you on zoological matters. The season is now over for collecting many things, but still I continue to pick up a little, and have received some valuable contributions from Arracan, \&c. since I last wrote. I have also just received a very interesting letter from Jerdon, announcing a valuable collection on its way to me, containing various novelties from Southern India, and I likewise expect two other collections from the peninsula shortly. In this neighbourhood I have just obtained another Cuculus canorus, also Phonicophaust ristis (Less. the longicaudatus of my first monograph on Cuculida), and one specimen of an Iöra, which proves, after all, that typhia and zeylonica are one and the same. This bird had about half acquired the black cap and back of zeylonica, the change of colour taking place in the feathers themselves without a moult. Yet it is strange, that of the great number of these birds which I have obtained both before and since, I have never procured another specimen with any trace of this zeylonica plumage. Add Rhipidurn albofrontata to the number of birds not found in this vicinity, but which occur on the eastern side of the mountains of Central India, 
extending to the Monghyr and Rajmahl hills. In my last letter I stated that the "Misham Yak," so called, was merely a S. African Gnoo, the frontlet of which had found its way to that distant locale ; but a friend who has travelled in the Misham mountains, N.E. Assam, assures me that he saw there two or three similar frontlets, and I have just seen a female head of this "Assam Gnoo," shot by the late Lieut. Seppings of the Bengal Artillery to the northward of Bishnath, one of our frontier stations towards Bootan; this settles the question of the animal being Asiatic, and I shall now have the male and female frontlets figured without further delay. Is it not an extraordinary discuvery to get a Gnoo in this part of the world ?perhaps more so even than that of the Shan Bison. [Ann. Nat. Hist. vol. xiii. p. 312.] It will not, however, inhabit the Misham mountains, which are densely covered with jungle, but the elevated plain beyond them. I shall come out very strong shortly, with a long list of new mammalia; and there seems no end to the number of new birds which $I$ have now by me to describe. Among a variety of interesting specimens in spirits, chiefly of reptiles and fishes, and comprising no less than three new Varani among the former, are various bats, comprising the genus Rhinopoma from Agra and Mirzapore. I had previously been quite convinced, from the descriptions of people, that a bat of this genus was abundant in the Taj at Agra. Phayre has now sent me, chiefly from the vicinity of Sandowa, Arracan, as many as 139 species of birds, and several capital Mammalia. In the collection just arrived from him are two new monkeys, which are doubtless, and one of them certainly, the two Cercopitheci mentioned by Helfer. One is a small Macacus, most allied to $M$. cynomolgus, and with a similar long tail; this I shall call $M$. cancrivorus, from its habit of feeding principally on crustacea. The other is a tremendously muscular fellow, closely allied to the pigtailed Macacus of Java (nemestrinus), and to the arctoides of Is. Geoffroy: it has a copious mane on its fore-quarters, from which I shall style it $M$. leoninus. I have also from the same quarter a new Paradoxurus, some new Sciurida, and more specimens of the new Manis, some of which I shall soon forward to Dr. Horsfield. Among the birds is a magnificent Lyncornis, Gould, which if new may be called $L$. splendidus. Length about 15 inches; of wing $11 \frac{1}{4}$. and tail $8 \frac{1}{2}$ in. ; the latter very broad, and the markings of it are superb, having alternate mottled ashy and mottled fulvous bands set off with black; there are no rictal vibrissæ, the feet are as in Caprimulgus, the wings firm and of considerable length, and the aigrette-like feathers on the sides of the head are, I know, as in Gould's genus. Do the other characters I have named also accord? The colour is difficult to describe without going much into detail; but the throat and breast are principally black, the shoulders of the wings bright bay, the head and tertiaries minutely mottled, with no large spots except along the middle of the crown. Does this brief description tally with either of Gould's species? Phayre has also sent a new genus resembling Pomatorhinus in all but the beak, which is straight and much less compressed, also not so much elongated: this I shall name Orthorhinus. Likewise 
several new Bulbuls; and of Nectariniida, Arachnothera inornata, Nect. goolpariensis, Phayrei (vel Hasseltii ?), mahrattensis, jugularis, lepida (v. javanica), and phonicotis, Diceum cruentatum, cantillans, and chrysochlorum, nobis, \&c. \&c. A shikaree in my employ has just come in with three specimens of Phoenicophaus tristis, a live young Nisaëtus caligatus, \&c.

XVII.-Remarks on the genus Eolidina of M. de Quatrefages. By Joshua Alder and Albany Hancock, Esqrs.

IN a former communication on the Nudibranchiate Mollusca, we took occasion to express an opinion that the genus Eolidina of M. de Quatrefages was not a good one, the species on which it was founded being, in our opinion, nothing more than an Eolis imperfectly observed. It was irrelevant to the object of our former paper to enter into detail on the reasons which induced us to form such an opinion, but as its accuracy is doubted by $M$. de Quatrefages, we shall now take the liberty of stating more fully our objections to his genus, in order that the facts connected with it may be more thoroughly investigated. It is not our wish to enter into personal controversy, but the validity of a genus is a matter of sufficient importance in zoology to justify our remarks, more especially as there are some anomalous facts in comparative anatomy connected with it.

On a careful examination of the description and figure which M. de Quatrefages has given of his new genus, we must again assert, that we can find no external character to distinguish it from Eolis. With reference to this he remarks, "that Eolidina wants the lateral or labial tentacles, and that all zoologists at present consider the presence or absence of these appendages as furnishing true generic characters." We must confess our inability exactly to understand what is here meant by "lateral or labial tentacles." Cuvier, in establishing the genus Eolis, described it to have four to six tentacles; but subsequent observations have proved that the third pair of tentacles of Cuvier are nothing more than prolongations of the sides of the foot, varying in length in each species and frequently entirely wanting. Later zoologists have therefore, we think very properly, considered Eolis to have no more than four tentacles, two dorsal, and two oral or labial. Now the species on which the genus Eolidina is founded has just this number of tentacles placed in the usual manner; it has also the anterior angles of the foot slightly produced, exactly as they appear in several species of Eolis; indeed so nearly does it approach to some of the English species, that doubts might be raised of its specific distinctness. If then Eolidina is a distinct genus, it must depend upon anatomical characters alone. We are 